\title{
Students' Misconception in Concept of Biology Cel
}

\author{
Hilarius Jago Duda \\ STKIP Persada Khatulistiwa Sintang Kalimantan Barat, Jl. Pertamina-Sengkuang, Indonesia, \\ hilariusjagod@yahoo.com \\ Adpriyadi \\ STKIP Persada Khatulistiwa Sintang Kalimantan Barat, Jl. Pertamina-Sengkuang, Indonesia, \\ adpriyadi@ymail.com
}

\begin{abstract}
Misconception is often experienced by students who study abstract subjects. If this misconception continues to be maintained then the next concept will be wrong and become a difficulty in the learning process, even if a teacher will continue the wrong concept to their students. Therefore, the researchers tried to analyze the misconceptions that occur in students who are already studying cell biology course. The research approach is qualitative with the research method used is descriptive. The study population was students of Biology Education STKIP Persada Khatulistiwa Sintang and the samples used were 30 students who had taken cell biology courses. Data collection techniques are diagnostic tests and interviews. Data analysis using Certainty of Response Index (CRI). The results obtained were misconceptions on the plasma membrane concept of $22.50 \%$, the concept of endoplasmic reticulum at $30.83 \%$, the concept of the golgi apparatus at $17.50 \%$, and the concept of ribosomes at $31.66 \%$. This data is categorized as high enough that students experience misconceptions, the rest is that students do not know the concept and know the concept. From the results of the study it was concluded that there were misconceptions on the four concepts in the cell biology subject.
\end{abstract}

Keywords: misconceptions, cel biology, student, biology, learning

\section{INTRODUCTION}

Abstract subjects will be difficult to understand by students. It is because the concepts that they learn cannot be seen directly so students are difficult to remember it, one of the subject that will be examined in this research is a cell biology subject. Cell biology is a study of the structure and function of cells in living things. Survey data showed that students considered that subject is one of difficult subjects to understand. Therefore, researchers are interested in seeing how far the depth of cell biology material has been studied by the students. So the researchers raised the theme of the misconceptions experienced by students in cell biology subject.

Misconception can take the form of an initial concept, where there is an incorrect relationship error between concepts, intuitive ideas or wrong views (Suparno, 2013). Researchers on misconception suggest that several things are cause of misconceptions in students. At main point, the causes of misconceptions can be summarized in five groups, namely: students, teachers, textbooks, contexts, and teaching methods. The causes that come from students can consist of several things, such as preconceptions, abilities, stages of development, interests, ways of thinking, and friends (Suparno, 2013). 
Hasan (1999) explained that misconception occurs in students if the level of student confidence is high in a concept that is considered wrong. Interpretation of situations that students got from the environment can be different from scientific conceptions that interfere with student learning. For this reason, misconception is eliminated as much as possible in the conceptual change process. According to Duda (2016) that misconceptions experienced by students can occur because of misinterpreting natural phenomena or events faced in his life. The misconceptions that were obtained by students at school still settled on him until he was in college. Misconceptions usually develop along with the learning process.

The misconceptions experienced by students can mislead students in understanding scientific phenomena and conducting scientific explanations. If students are not aware of the occurrence of misconceptions, there will be confusion and incoherence in students. If it is not immediately fixed, the misconception will be an obstacle for students to further understanding in the learning process. Students are aware of the misconceptions that happened, it would be easier to change and improve their misconceptions. Students will be able to form concept connections by themselves too. In addition, students will easily decide which is right and wrong about a concept. Furthermore, students can also construct and reconstruct their conceptions actively. According to Duda, et al (2019) we know that the function of education as transfer of values and knowledge explains why education is a significant way forward.

Cells are fundamental to biology as well as atoms for chemistry. All organisms consist of cells. In the order of biological organization, this cell is the simplest collection of material that can live. There are single-celled organisms such as prokaryotes, namely microorganisms and the other one is multicellular such as eukaryotic cells, namely animal / human and plants (Champbel, 2002). In this research, the cell biology concept that researched was plasma membrane, endoplasmic reticulum, Golgi apparatus, and ribosome. The questions made were covering these concepts to express misconceptions from students.

The concept of cell biology was chosen not only because the concept is abstract and difficult to understand because in the concept many students find it difficult to understand and the low learning outcomes of the concept. The research is expected to find misconceptions that occur in students and in the future can provide solutions to overcome these misconceptions. So the misconceptions that occur do not last long and are not passed on to the next generation. Therefore, this research can make an important contribution for students and teaching staff.

The formulation of the research problem is first, how is the misconception of biology education students in the cell biology course of the concept of plasma membrane, endoplasmic reticulum, golgi apparatus, and ribosome. Second, what factors are causing the misconception of biology education students in the cell biology course of the concept of plasma membrane, endoplasmic reticulum, golgi apparatus, and ribosome. The aim of the research is first, to reveal how many misconceptions experienced by biology education students in the cell biology courses of the concept of plasma membranes, endoplasmic reticulum, golgi apparatus, and ribosomes. Second, to find out what factors cause misconceptions in the cell biology course of the concept of plasma membrane, endoplasmic reticulum, golgi apparatus, and ribosome.

\section{METHOD}

\section{Research Method}

The research approach used is qualitative. This research method using descriptive methods that did not provide treatment, manipulation or change to independent variables, but describe a condition as it is. Research Qualitative has the characteristics of having a natural setting, meaning that research is done in a reasonable and realistic situation from a real phenomenon, setting naturally is a source of data, the 
researcher himself acts as research instrument (Sugiyono. 2014). The data collection was done by using a diagnostic test and interview techniques. Test techniques used instruments such as structured essay questions. In each question, students are asked to complete the questions with short right answer. Respondents must also write an index of confidence in the answer or the Certainty of Response Index (CRI) (Hasan, et al, 1999). CRI is number 1-5. Next, interviews were conducted for students who experienced misconceptions to find out the causes of misconceptions. Interview guides are arranged according to the concepts of cell biology under study.

\section{Population and Sample}

The populations in this study were all students who had taken cell biology subject in study program biology education 4th semester STKIP Persada Khatulistiwa Sintang, Indonesia. The sample used was 30 students who were selected by purposive sampling. Diagnostic test instruments were first tested to determine the validity, reliability, level of difficulty, and distinguishing power. Furthermore, CRI analysis was conducted to differentiate students who knew the concept, did not know the concept, and experienced misconceptions based on a combination of right or wrong answers and high and low CRI student answers.

\section{Data Analysis}

Data analysis of misconceptions in this study was conducted in accordance with CRI analysis that conducted by Hasan (1999). CRI is a measure respondents' level confidence or certainty in answering each question given. A low CRI signifies concept uncertainty in the respondent in answering a question, otherwise a high CRI reflects a high level of concept confidence and certainty in respondents. CRI is developed on a scale of six $(0-5)$ as in Table 1.

Table 1

\begin{tabular}{ll}
\multicolumn{2}{c}{ CRI and Its Criteria } \\
\hline CRI & Criteria \\
\hline 0 & (Totally guessed answer) \\
1 & (Almost guess) \\
2 & (Not Sure) \\
3 & (Sure) \\
4 & (Almost certain) \\
5 & (Certain) \\
\hline
\end{tabular}

To clarifying in scoring, then the following table will explain provision to distinguish between knowing concepts, misconceptions, and not knowing the concepts for individual respondents.

Table 2

CRI Analysis based on Answer Criteria

\begin{tabular}{|c|c|c|}
\hline Answer Criteria & Low CRI $($ CRI $<2,5)$ & High CRI (CRI > 2,5) \\
\hline Correct Answer & $\begin{array}{l}\text { Correct answer but Low CRI did not } \\
\text { know the concept }\end{array}$ & $\begin{array}{l}\text { Correct answer and High CRI mastered } \\
\text { the concept well }\end{array}$ \\
\hline Wrong Answer & $\begin{array}{l}\text { Correct answer and Low CRI did not } \\
\text { know the concept }\end{array}$ & $\begin{array}{l}\text { Correct answer and High CRI appeared } \\
\text { misconception }\end{array}$ \\
\hline
\end{tabular}

Based on Table 4.2, it can be explained that if the answer is correct but the CRI is low this means that you don't know the concept (lucky guess). If the answer is correct and CRI High, it means mastering the concept well (know the concept). If the answer is wrong and CRI is low, it means they don't know the concept. And if the answer is wrong but the CRI is high, it means misconception. After that, the percentage of each criterion is calculated with the following formula:

$$
\begin{aligned}
& \text { X Percentage }=\text { X/N X } 100 \% \\
& \text { Y Percentage }=\text { Y } / \text { N X } 100 \% \\
& \text { Z Percentage }=\text { Z/N X } 100 \%
\end{aligned}
$$


Description:

$\mathrm{X}=$ Number of Students Who Know the Concept

$\mathrm{Y}=$ Number of Students Who Don't Know the Concept

$\mathrm{Z}=$ The number of students who misconception

$\mathrm{N}=$ Total Student

Then an analysis of students 'understanding of each subconcept was carried out by adding up the percentage of students who knew the concept, did not know the concept of each subconcept based on the students' answers to each test question. To find out the causes of misconceptions, interviews were conducted with of 10 students representing those experiencing misconceptions.

\section{FINDINGS}

Based on the research that has been done on the analysis of the misconception of biology education students in the cell biology subject of plasma membrane conceptions, endoplasmic reticulum, golgi apparatus, and ribosomes with the CRI method, the results were obtained as shown in Table 3

Table 3

Results of Student Misconceptions

\begin{tabular}{|c|c|c|c|c|c|c|c|c|}
\hline NO & Concept & $\begin{array}{l}\text { Questions } \\
\text { Indicator }\end{array}$ & 1 & 2 & 3 & 4 & 5 & $\begin{array}{l}\text { Total } \\
\text { Percentage }\end{array}$ \\
\hline \multirow[t]{5}{*}{1} & Plasma & Know the concept (\%) & 37,50 & 41,67 & 37,50 & 4,17 & 91,67 & 42,50 \\
\hline & Membranes & Do not know the concept & 16,67 & 45,83 & 29,17 & 79,17 & 4,17 & 35,00 \\
\hline & & Misconception & 45,83 & 12,50 & 33,33 & 16,67 & 4,17 & 22,5 \\
\hline & & questions & 6 & 7 & 8 & 9 & 10 & \\
\hline & & Indicator & & & & & & \\
\hline \multirow[t]{3}{*}{2} & Endoplasmic & Know the concept & 29,17 & 29,17 & 45,83 & 8,33 & 45,83 & 31,67 \\
\hline & Reticulum & Do not know the concept & 45,83 & 29,17 & 41,67 & 37,50 & 33,33 & 37,5 \\
\hline & & Misconception & 25,00 & 41,67 & 12,50 & 54,17 & 20,83 & 30,83 \\
\hline \multirow[t]{5}{*}{3} & Golgi & questionc & 11 & 12 & 13 & 14 & 15 & \\
\hline & & Indicator & & & & & & \\
\hline & & Know the concept & 66,67 & 37,50 & 41,67 & 41,67 & 62,50 & 50,00 \\
\hline & & Do not know the concept & 20,83 & 45,83 & 20,83 & 41,67 & 33,33 & 32,49 \\
\hline & & Misconception & 12,50 & 16,67 & 37,50 & 16,67 & 4,17 & 17,50 \\
\hline \multirow[t]{5}{*}{4} & Ribosomes & question & 16 & 17 & 18 & 19 & 20 & \\
\hline & & Indicator & & & & & & \\
\hline & & Know the concept & 20,83 & 12,50 & 29,17 & 58,33 & 54,17 & 35 \\
\hline & & Do not know the concept & 33,33 & 45,83 & 29,17 & 33,33 & 25,00 & 33,33 \\
\hline & & Misconception & 45,83 & 41,67 & 41,67 & 8,33 & 20,83 & 31,66 \\
\hline
\end{tabular}

Based on the data from the research in Table 3, it could be seen that in the plasma membrane concept there were still quite number of students who experienced misconceptions where the number was $22.50 \%$, while those who did not know the concept were also quite large, $35 \%$ and $42.50 \%$. In the concept of endoplasmic reticulum, it was seen that students who known the concept were $31.67 \%$, students who did not know the concept were $37.50 \%$, and those who experience misconceptions were $30.83 \%$. The concept of the Golgi apparatus showed that students who known the concept were 50\%, students who did not know the concept were $32.49 \%$ and students who experienced misconceptions were $17.50 \%$. The ribosome concept showed that students who known the concept are $35 \%$, students who did not know the concept are $33.33 \%$ while students who experienced misconceptions are $31.66 \%$.

\section{DISCUSSION}

From these data it could be seen that there were still quite large data of students who experienced misconceptions and those who did not know the theory, this was because there were allegedly several 
causes of students still experiencing misconceptions and not knowing the theory, including those concepts which were difficult to understand because its nature was abstract and could not be seen directly with the eye or could not be felt by the five senses that exist. This was supported by Rahayu (2011) statement that misconception could be caused by the material being too complex and not in accordance with students' thinking patterns, the material discussed was still unfamiliar for students. Conception was also caused by the wrong concept taught by the teacher at the previous level. The causes of misconceptions in students' understanding, namely limited information received, limited possibilities to test new theories, errors in textbooks, information from the media that is incorrectly delivered, students were always passive and accept what they were from the teacher.

From the interviews it was found that the cause of the misconception was the source of learning both print and online such as teaching materials or textbooks used which could also cause misconceptions, as expressed by Fitrianingrum et al. (2013: 78) states that "high school students' misconceptions are mostly caused by textbooks". Misconceptions are also caused by previous learning resources obtained or read by students, for example when schools are obtained from school teachers or others, this is supported by a statement according to Rahayu (2011) that misconceptions experienced by students can come from everyday experiences when students interact with their environment . Suparno (2013: 29) argues that "misconceptions can be caused by several factors including students, teachers, textbooks, contexts, and teaching methods". Many studies reveal the misconceptions experienced by teachers (Nehm and Schonfeld, 2007; Yates and Marek, 2013). Bishop and Anderson (1990) explain that many of the teacher's misconceptions are the same as those experienced by students.

The results of the interview found that misconceptions were also influenced by theoretical understanding of the concept below from junior high school or senior high school whether it was from a teacher at school or a colleague.The students before entering the biology learning process formally on campus have brought the initial concept of biology. The initial concept that was carried out was sometimes not appropriate or contrary to the concept accepted by experts. This different concept is often referred to as an alternative misconception or concept. They got the initial concept when they were in elementary school, high school, from their experiences and observations in society or in everyday life (Berg, 2004).

The results of the interview also found that the cause of the misconception was from information obtained through information technology. According to Widha (2009) The results of research from various countries indicate that the misconceptions experienced by students are caused by inappropriate applications and use of media that cannot describe the concepts being studied. Another opinion explains that misconception is influenced by the process of forming knowledge in the minds of students.

\section{CONCLUSION}

Based on the results of the data analysis and discussion, it can be concluded that there are still many students who experience misconceptions either every concept of cel biology or whole. In the plasma membrane concept where $22.50 \%$, of students experience misconceptions, in the concepts of endoplasmic reticulum the percentage of students who were categorized as experiencing misconception is $30.83 \%$, in the concept of the golgi apparatus students who experienced misconceptions were $17.50 \%$, in the ribosome concept students who experienced misconceptions were $31.66 \%$. Of course this will have an impact on the process and also the application of the cel biology, therefore, this needs to be addressed and corrected the misunderstanding of the concept. Factors causing the misconception are in addition to the difficult and abstract concept of cel biology as well as many foreign terms also caused by misconceptions in print media such as books or print journals, online media, teaching staff (teachers or lecturers), peers, information from technology or other environmental factors. 


\section{SUGGESTIONS}

From the research, the researcher can suggest that this misconception research needs to be done on another biology concept because remembering that biology courses are subjects which are generally abstract in nature so that it is possible to always find misconceptions. In addition, further research is needed to overcome the misconceptions that often occur in biology education students. This research is very beneficial for science because it can correct the wrong cell biology concepts both in learning resources or in the wrong understanding experienced by teachers and students so that they can continue their knowledge to the next generation correctly and correctly and can also be rightly in the application of science.

\section{REFERENCES}

Berg EVD. (2004). Alternative conceptions in physics and remediation. Philippines: Science and Mathematics Education Institute University of San Carlos.

Bishop, B. A., \& Anderson, C. W. (1986). Student conception of natural selection and its role in evolution. The Institute for Research on Teaching: Michigan State University.

Chapbell, N. A., Reece, J. B., \& Mitchell, L.G. (2002). Biologi. Edisi ke 5 jilid 1. Penerbit Erlangga.

Dahar, R.W. (2004). Teori- teori Belajar. Jakarta: Erlangga.

Duda, H. J. (2016). Analysis of genetic misconceptions student biology education at STKIP Persada Khatulistiwa Sintang. International Conference on Education, Education in the 21th Century: Responding to Current Issues, Graduate School, Universitas Negeri Malang.

Duda, H. J., Susilo, H., \& Newcombe, P., (2019). Enhancing different ethnicity science process skills: Problem-based learning through practicum and authentic assessment. Int. J. of Ins., 12(1), 1207-1222.

Fitrianingrum, N., Sunarno, W., \& Harjunowibobo, D. (2013). Analisis Miskonsepsi Gerak Melingkar pada Buku Sekolah Elektonik (BSE) Fisika SMA Kelas X Semester I, J Pend. Fisika, 1(1): 73-80.

Hasan, S., Bagayoko, D., \& dan Kelley, E. L. (1999). Misconceptions and the certainty of response index (CRI). Phys.Educ, 34, 295.

Mbulu, Joseph, \& Suhartono. (2004). Pengembangan Bahan Ajar. Malang: Penerbit Elang Mas.

Nehm, R. H., \& Schonfeld, I. S. (2007). Does increasing biology teacher knowledge of evolution and the nature of science lead to greater preference for the teaching of evolution in schools? Journal of Science Teacher Education. 18: 699-723.

Rahayu, A. A. (2011). Penggunaan Peta Konsep Untuk Mengatasi Miskonsepsi Siswa Pada Konsep Jaringan Tumbuhan (Penelitian Tindakan Kelas Di MAN 10 Jakarta). Program Studi Pendidikan Biologi Jurusan Pendidikan Ilmu Pengetahuan Alam, Fakultas Ilmu Tarbiyah Dan Keguruan, Universitas Islam Negeri Syarif Hidayatullah Jakarta.

Sugiyono. 2014. Metode Penelitian Kuantitatif, Kualitatif, dan R\&D. Bandung: Alfabeta.

Suparno, P. (2013). Miskonsepsi dan Perubahan Konsep Dalam Pendidikan Fisika. Jakarta: Grasindo.

Yates, T. B., \& Marek, E. A. (2015). Is Oklahoma really OK? A regional study of the prevalence of biological evolution-related misconceptions held by introductory biology teachers. Evolution: Education and Outreach, 6(6), 1-20. 